\title{
A review on effective utilization, phytochemical compounds, pharmacological intervention of a popularly used plant for developing a new drug: Zanthoxylum armatum with reference to its anticancer activity
}

\begin{abstract}
The plant domain had great contribution in providing the health benefits to society when no concept of synthetic medicines and surgical management existed. Since it is a fact that native communities are highly knowledgeable about plants and other natural resources on which they are highly dependent, these medicinal plants are used by the local inhabitants to treat many diseases.

Zanthoxylum armatum (Rutaceae) is a unique plant which grows everywhere and is quite popular among tribes for its vast medicinal properties, known to them by their ancestor since ages. People of Arunachal Pradesh of India, Nepal, Pakistan regularly use this seeds for culinary purpose while cooking meat, chew it regularly for any tooth ailments, to expel worms. It is available indigenously all around the subtropic valleys of Himachal Pradesh and North East region of India. This plant is considered as a divine plant in contiguous areas. The seeds contain many important phytoconstituents and essential oils which contribute to its biological activities including larvicidal, anti-inflammatory, analgesic, antinociceptive, antioxidant, antibiotic, hepatoprotective, antiplasmodial, cytotoxic, antiproliferative, anthelminthic, antiviral and antifungal.

The plant has been reviewed thoroughly since the year 1830 and many research papers, reviews were published on its medicinal properties. However, anti cancer properties of the plant is not having any folk lore claim. During our literature survey, its immense medicinal properties and potential as a new chemical entity as anticancer agent were revealed which were not reported earlier. Many new phytochemical compounds were found. Methanol extract and the crude saponins from fruit, bark and leaves of $Z$. armatum for its anticancer effects on breast, colon cancer has been reported recently. Every parts of the plant, be it stem bark, leaves, fruits possess medicinal properties, unlike many other plants, which made this plant unique and fascinating. Hence we attempted to compile an account of the plant, work done so far and future strategies of research work, so that this useful plant can be utilized to its fullest extent for the health benefit of mankind and animals
\end{abstract}

Volume 5 Issue 3 - 2018

\author{
Chandana Choudhury Barua,' Nilofar \\ Yasmin,' R Elancheran ${ }^{2}$ \\ 'Department of Pharmacology and Toxicology, College of \\ Veterinary Science, Assam Agricultural University, Assam, India \\ ${ }^{2}$ CSIR-SRF, Drug Discovery Lab, Institute of Advanced Study in \\ Science and Technology, India
}

Correspondence: Chandana Choudhury Barua, Department of Pharmacology and Toxicology, College of Veterinary Science, Assam Agricultural University, Guwahati-78I 022, Assam, India, Tel 986401323I,Email chanacin@gmail.com

Received: May 31, 2018 | Published: June 27, 2018

Keywords: cytotoxicity, phytoconstituents, therapeutics efficacy, traditional medicine; zanthoxylum armatum

Abbreviations: DPPH, 1,1-diphenyl-2-picrylhydrazil radical; MEZA, methanol extract of Zanthoxylum alatum; EAC, ehrlich ascites cancer; NRU, neutral red uptake; DEPA, N, N-diethyl phenyl acetamide; DEET, N, N-diethyl-m-toluamide; DMP, dimethyl phthalate; NBP, N-benzoyl piperidine; PTZ, pentylenetetrazole; ZAP, zanthoxylum alatum planispinu; ZAS, zanthoxylu alatum subtrifoliatum; MAPK, mitogen-activated protein kinases

\section{Introduction}

Zanthoxylum armatum, an important medicinal plant which is known as Indian prickly shrub: Nepal pepper or toothache tree. Locally this plant is known as Tejphal in Hindi, Tejowati in Sanskrit, Timur in Nepali and Mukthrub in Manipuri, Szechuan pepper in China; it is widely spread in N.E India.

Traditionally it is used by the Bhotiya communities for food, medicines and exchange in the Uttaranchal, Himalaya of India. The
Zanthoxylum armatum fruit is used by the Bhotiyas of Pithoragarh district of Kumaon region while those of the Kamoli district of Garhwal have developed the collection and trade of Z. armatum sticks to pilgrims visiting the shrines of Badrinath, Kedarnath, Gangotri and Yamunotri. ${ }^{2}$ The fruits, bark and leaves are used as spice, in the Indian medicine system.

\section{Definition}

Zanthoxylum armatum known as winged prickly ash is a species of plant in the Rutaceae family. It is an aromatic deciduous, spiny shrub growing to 3.5 meters in height, endemic to China, Japan, Korea and India. Zanthoxylum armatum is a wild plant and mostly used as a condiment and medicine and have other medicinal properties.

\section{Synonyms}

Z. alatum planispinum, Z. alatum subtrifoliatum 


\section{Common name}

Commonly known as the Winged Prickly Ash, Prickly Ash, Tumburu, Suterberry, Yellow wood. In Hindi it is known as Tejphal, Darmar, Tumru, Trimal. In Manipuri it is known as Mukthurubi, in Telegu it is known as Konda-Kasimi and in Nepali it is known as Timur.

\section{Taxonomic classification ${ }^{3}$}

Botanical name

Family

Kingdom

Sub kingdom

Domain

Phylum

Sub phylum

Infra phylum

Class

Magnoliopsida

$$
\begin{aligned}
& \text { Sub class } \\
& \text { Super order }
\end{aligned}
$$

Order

Sub order

Genus

Zanthoxylum

\section{Distribution}

Zanthoxylum armatum tree are extensively distributed worldwide. Countries like China, Japan, Korea, Taiwan, Bangladesh, Bhutan, Nepal, Pakistan, Laos, Myanmar, Thailand, Vietnam and Indonesia also grow Zanthoxylum armatum. Various states in India, Andhra Pradesh, Jammu and Kashmir, Assam, Manipur, Meghalaya, Nagaland, Orissa, Uttar Pradesh has different varieties of the tree. ${ }^{4}$ Zanthoxylum armatum is largely found in India from Jammu and Kashmir to Bhutan at an altitude of approximately $2500 \mathrm{~m}$ and mostly found in North-East India. Wastelands, mountains, valleys, forest areas are the main habitual locations of the species. ${ }^{5}$

\section{Description}

The tree (Figure 1) contains small flowers having color pale yellow and are bisexual, Shrubs, woody climbers, or trees to $5 \mathrm{~m}$ tall, deciduous. Branch lets and leaflet blades axially on mid vein usually with prickles. Young branch lets and inflorescence rachises glabrous or rust-colored pubescent. Leaves 3-9 foliolate; rachis glabrous or rust-colored pubescent, wings to $6 \mathrm{~mm}$ on each side; leaflet blades sub sessile, opposite, lanceolate, ovate, or elliptic, 3-12 cm long, 1-3 $\mathrm{cm}$ wide, base attenuate to broadly cuneate, secondary veins $7-15$ on each side of midvein and generally faint, margin crenate or entire and often revolute when dry, apex acute to acuminate. ${ }^{6}$ (Figure 2).

The flowering season starts in July and ends in August. Male flowers: stamens 4-6; anthers yellow prior to anthesis; connective apex with oil gland; disk pulvinate; rudimentary carpals lacking. Female flowers: carpels 2 or 3, axially often with a conspicuous oil gland; styles recurved; staminodesligulate or lacking (Figure 3). The fruiting season begins in October to November. Fruit follicles usually purplish red, $4-5 \mathrm{~mm}$ in diameter, with a few protruding oil glands (Figure 4). Seeds, blackish brown, 3-4 mm in diameter. Seed are rounded, $3 \mathrm{~mm}$ in diameter, shining black. The prickles often vertically flattened on the trunk and branches the older with corky base, it rapidly changes color on exposing to light from yellowish brown to dark brown. bark pale brown in color, texture is rough croaky, leaves are alternate imparipinnate. ${ }^{7}$ (Figure 5).

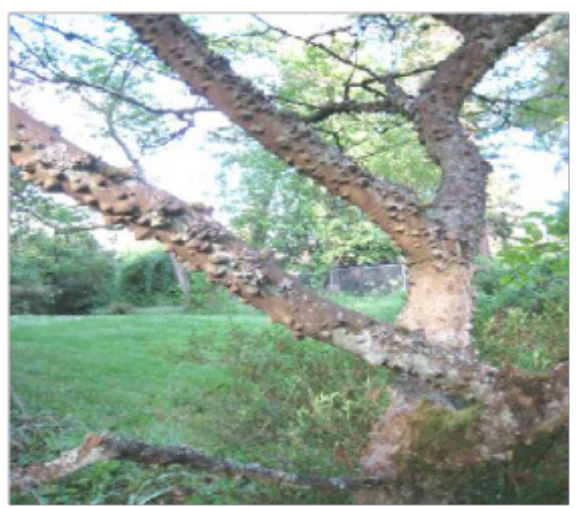

Figure I Zanthothoxylum armatum tree.

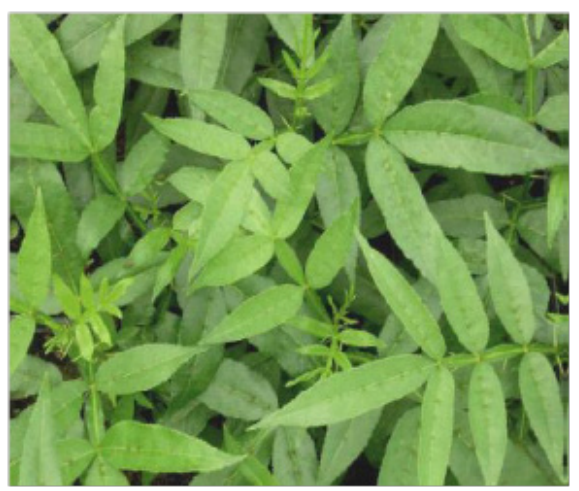

Figure 2 Leaves of $Z$ armatum.

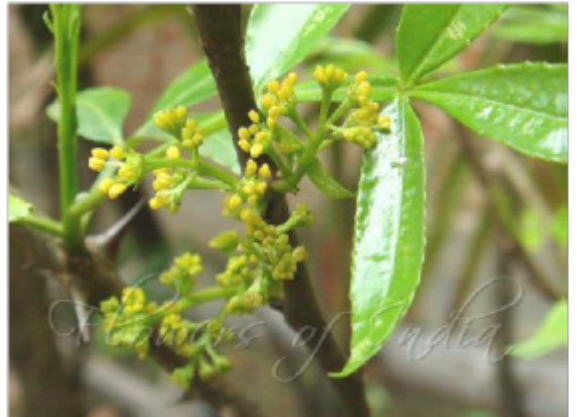

Figure 3 Flowers of $Z$ armatum.

\section{Plant material of interest: seeds, fruits, bark and stem}

\section{General appearance}

In Unani system of medicine, the fruits, seeds and bark are used. It is a small thorny tree or shrub up to $6 \mathrm{~m}$ high with dense foliage and mainly found in the Himalayas at an altitude of 1000 to $2100 \mathrm{~m}$, high. 
It's branches have nearly straight prickles up to $1.2 \mathrm{~cm}$ long. Leaves are distinctively trifoliate with the leaf-stalk winged. Leaflets are stalk less, 2.0-7.5 $\times 1.0-1.7 \mathrm{~cm}$, ellipticto ovate-lace like, sharp tipped, base sometimes oblique. The fruits are reddish brown sub-globose and contains a single seed in follicle. Seeds are globose, glabrous and shiny black.

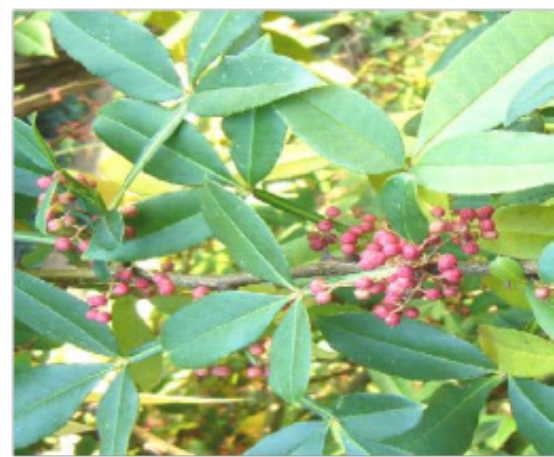

Figure 4 Fruits of Z.Armatum.

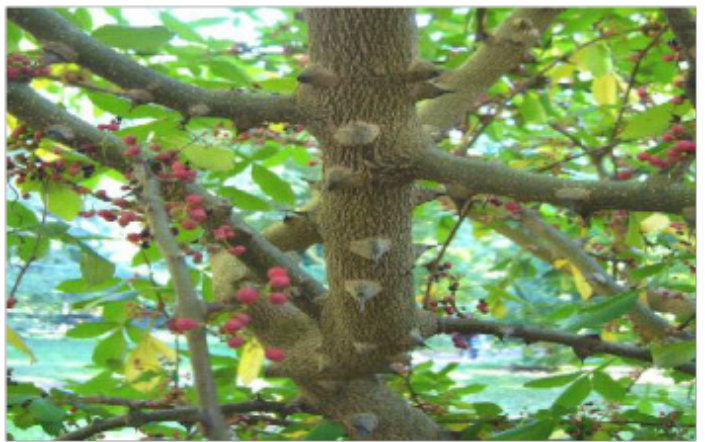

Figure 5 Bark of Z.Armatum.

\section{Climate and soil}

The plant generally grows well in sufficient rainfall. The plants are generally seen in the open pastures and clean forest areas. It requires shallow well-drained damp retentive soil under semi-shaded or in full sun. Flowers are also formed in the old wood. ${ }^{5}$

\section{Propagation material}

Seed is mostly sown in the autumn. In the month of June and July mostly the seeds are collected. When the seeds are in less quantity terminal stem cuttings are generally used as propagules. Germination of seeds normally takes in late spring. ${ }^{5}$

\section{Agro-technique ${ }^{5}$}

The propagules are raised in two ways by developing nursery or by sowing seeds in field. In the month of August and September the seeds are planted in the nursery. The seeds within twenty to thirty days germinated. Seedlings are transplanted to the field when they reach a height of 20 to $30 \mathrm{~cm}$. Cold stratification is required for three months for stored seeds which germinate in the month of February and March. Ten to twelve tones of manure are used for per hectare of the soil as a fertilizing component before the transplantation. Using cultivator the land should be ploughed two to three times. The plant can be grown as single crop or mixed crop with herbaceous species as well. Regular irrigation is required for the establishment stage. The plant is normally free from any physiological disorders (Figure 6).

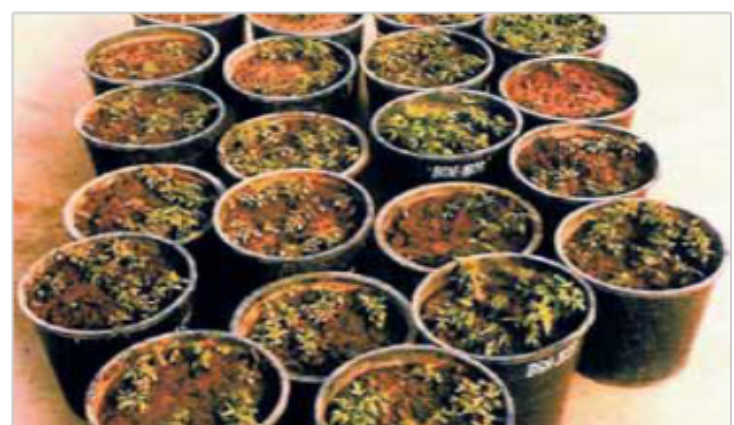

Figure 6 Zanthoxylum armatum - nursery.

\section{Harvest management ${ }^{5}$}

Flowering is generally seen on five year old plants. The crop takes five to seven years to be fully matured. After the harvest the fruits and herbage is dried in the sun. The fruits are cut into pieces for taking out the seeds. Fresh and dry fruits yield almost twenty quintals per hectare and six quintals per hectare respectively. Total cost is estimated to be 30,0000 per hectare.

\section{Macroscopic characters ${ }^{8}$}

Leaves stem bark and fruit of Zanthoxylum armatum were evaluated on morphological parameters. The observations for size, color, shape, texture, fracture, taste and odor were noted for leaves, bark and fruit (Table 1).

Table I Organoleptic evaluation of Zanthoxylum armatum leaf, bark and fruit

\begin{tabular}{|c|c|c|c|}
\hline Parameters & Leaves & Bark & Fruit \\
\hline Color & $\begin{array}{l}\text { Dark green upper surface, light } \\
\text { green lower surface }\end{array}$ & Pale brown & $\begin{array}{l}\text { Greenish brown, seeds are } \\
\text { black brown }\end{array}$ \\
\hline Shape & $\begin{array}{l}\text { Lanceolate, acuminate, } \\
\text { inparipinnate }\end{array}$ & $\begin{array}{l}\text { Flat with grayish brown spots due to removed spines. } \\
\text { Spines are short with rounded base }\end{array}$ & Rounded, spherical \\
\hline Size & $\begin{array}{l}\text { Small leaves } 2.3-3 \mathrm{~cm} \text {, large } \\
\text { leaves } 12-14 \mathrm{~cm}\end{array}$ & Variable & $5 \pm 0.2 \mathrm{~mm}$ \\
\hline Taste & Spice & Bitter & Acrid \\
\hline Odor & Aromatic, spicy & Characteristic & Aromatic \\
\hline Fracture & Brittle when dry & When fresh break with almost straight edges & $\begin{array}{l}\text { Hard, fruit envelop breaks } \\
\text { into small size pieces }\end{array}$ \\
\hline $\begin{array}{l}\text { Powder drug } \\
\text { study }\end{array}$ & & & \\
\hline
\end{tabular}

Citation: Barua CC, Yasmin N, Elancheran R.A review on effective utilization, phytochemical compounds, pharmacological intervention of a popularly used plant for developing a new drug: Zanthoxylum armatum with reference to its anticancer activity. MOJ Bioequiv Availab. 20I8;5(3):I56-I67. DOI: I0.15406/mojbb.2018.05.00097 


\begin{tabular}{|c|c|c|c|}
\hline Parameters & Leaves & Bark & Fruit \\
\hline Color & Greenish brown & Brown & Dark brown \\
\hline Odor & Slight & Characteristic, aromatic & Aromatic \\
\hline Taste & Slightly oily & Slightly bitter and astringent afterwards & Astringent, aromatic \\
\hline $\begin{array}{l}\text { Filter paper } \\
\text { test* }\end{array}$ & + & + & ++ \\
\hline
\end{tabular}

*Filter paper test for presence of fixed and volatile oils; +, Only volatile oils are present; ++ , Both fixed and volatile oils are present.

\section{Microscopic studies ${ }^{9}$ (Table 2)}

Table 2 Quantitative microscopic and physicochemical parameters for Zanthoxylum armatum leaf, bark and fruit. ${ }^{9}$

\begin{tabular}{ll}
\hline Parameters & Value \\
\hline Vein termination number & $24-28$ \\
Vein islet number & $24-26$ \\
Palisade ratio & 3.83 \\
Stomatal index & $15 \pm 2$
\end{tabular}

Ash values (\%)

Bark

Total ash

Water soluble ash

$8.45 \pm 1$

Acid insoluble ash

Leaves

Total ash

$21.725 \pm 2.5$

Water soluble ash

$4.06 \pm 1$

Acid insoluble ash

| $6.4 \pm$ I

Fruit

Total ash

$25.255 \pm 2$

Water soluble ash

$7.76 \pm 1$

Acid insoluble ash

LOD $\mathrm{mg} / \mathrm{MI}$

Bark

Leaves

Fruit

Extractive values with organic solvents $(\mathrm{mg} / \mathrm{ml})$

Bark

Methanol

$21 \pm 1$

Ethyl acetate

$9.35 \pm 3.1$

Chloroform

Hexane

$9.9 \pm 2$

Leaves

Methanol

Ethyl acetate
Chloroform

$10.5 \pm 1$

Hexane

Fruit

Methanol

|4.34 I

Ethyl acetate

$12.15 \pm 1.1$

Chloroform

$10.6 \pm 1$

Hexane

$7.4 \pm 0.5$

\pm , Calculated as SEM of three readings; SEM, standard error of the mean; LOD loss on drying.

\section{Phytochemistry ${ }^{7,10}$}

Zanthoxylum armatum consists of the following constituents extracted from different parts of the plant i.e. seed, leaves, fruit, root and barks etc. which are alkaloids, flavonoids, saponin, tannins, steroids, terpenes, glycosides, carbohydrates, phenolic, proteins, essential oil and amino acids, Viz., arginine, aspartic and glutamic acid, glycine, histidine, threonine, tyrosine. Bark contains lignans as sesamin, fargesin, eudesmin, epieudesmin, a neutral lactone as pulvatide, dictamine, 8-hydroxyl dictamine, y-fagarine, magnofluorine, xanthoplanine, triterpenoids as $\beta$-amyrin and amyrenone. The fruit contains flavanoids as tambulinandtambulol; linalool, essential oil containing citral, limonene, sabinene, linalyl acetate, geraniol, methyl cinnamate, cineole, monoterpentriols as 3,7-dimethyl - 1 octane - 3,6,7 - triol, trans- cinnamic acid, nevadensin, umbelliferone, $\beta$-sitosterol and its glucoside. The aerial part contains sitosterol and pinoresinol diethylether. The oil from leaves contain methyl-n-nonyl ketone, linalyl acetate, sesquiterpene hydrocarbons, acids, phenols, 1, 8-lineole, limonene, citronellal and tricosane. The wood contains magnoflurine and xanthoplanine.

\section{Isolation and characterization of chemical constituents}

\section{a. GC-MS analysis of hexane extract of Zanthoxylum armatum}

We have used GC-MS technique, ${ }^{11}$ to identify the chemical compounds present in the extract. Hexane extract of Zanthoxylum armatum yielded pale yellow colored oil $(8.3 \mathrm{ml} \mathrm{w} / \mathrm{v})$ and separation of the components are done by gas chromatography and identified by comparing the MS with the standard. Examination of oil of hexane extract of Zathoxylum armatum by GC-MS revealed the presence of several chemical compounds. Gas chromatogram is shown in Figure 7.

The identification of the peaks was executed by the retention time (RT), $\lambda$ max and mass spectra of $Z$. alatum extract from the earlier literature and database. The active compounds are Silane,2-butenylmethoxymethyl, 4H-Pyran-4-one, 2,3-dihydro-3, 5,Silane,[(1,1-dimethyl-2-propen)], 2-Cyclohexen-1-one, 3-methyl,

Citation: Barua CC,Yasmin N, Elancheran R.A review on effective utilization, phytochemical compounds, pharmacological intervention of a popularly used plant for developing a new drug: Zanthoxylum armatum with reference to its anticancer activity. MOJ Bioequiv Availab. 20I8;5(3):I56-I67. 
1-Methyl-pyrrolidine-2-carboxylic,

4-(2-Hydroxyethyl)-2,2- Silane, dimethyl, 1,2,4-Trimethoxybenzene, Hexadecane, Silane,[3- 13-[(1-Phenylethylimino)methyl (2,3-epoxypropoxy)pr, Quinoline, decahydro-1-methyl,

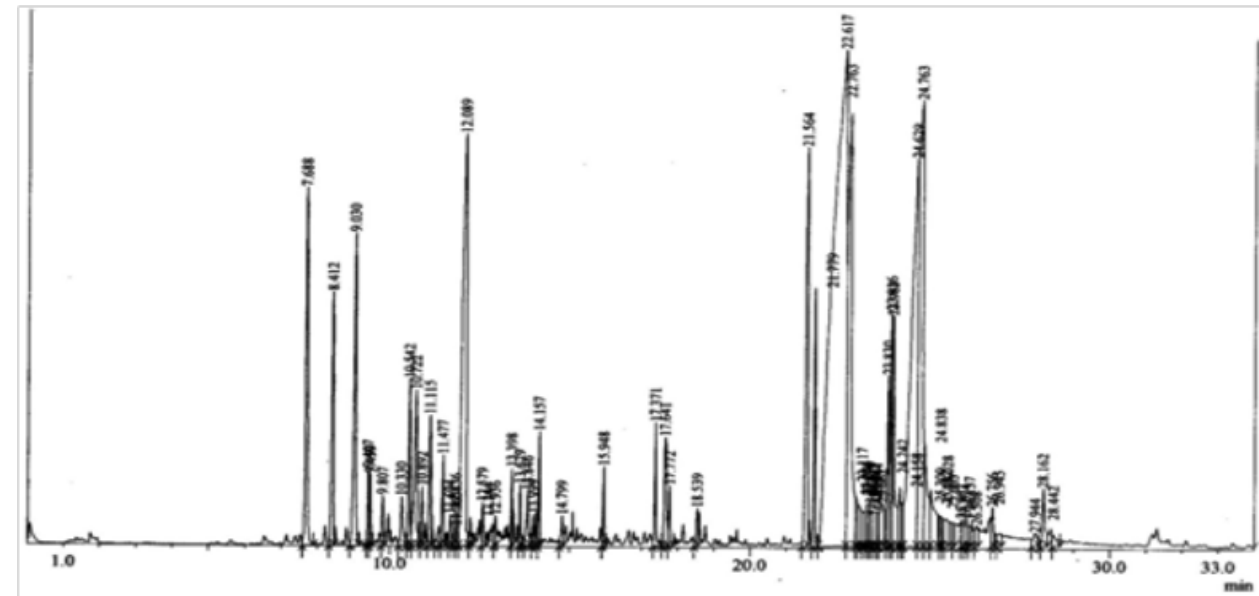

Figure 7 GC-MS chromatogram of hexane extracts of fruits of plant Zanthoxylum armatum.

\section{Identification of phenolic compounds from Z. alatum}

The rapid screening of the compounds present in the $Z$. alatum hydroalcoholic extract was confirmed using chromatographic analysis by using LC- ESI-MS/MS. ${ }^{12}$ Initially, there are different gradient solvents were used for the chromatographic separation. Of these, the results were obtained well using $10 \mathrm{~min}$ run time. The gradient method was well optimized for the identification of the phytoconstituents present in Z. alatum extract. The chromatogram was recorded at 365 $\mathrm{nm}$. The chromatographic representation is illustrated in Figure 8.

The identification of the peaks were executed by the comparison of the retention time (RT), $\lambda$ max and mass spectra of the $Z$. alatum extract. Peaks with RT (min) of 1.70, 2.08, 9.31, 9.53 (peaks 1-4) were identified as the following: Hesperidin, Magnoflorine, Melicopine, Sesamin (Figure 9) (Table 3).

Table 3 Peak identification of Z. alatum extract by using LC-MS/MS

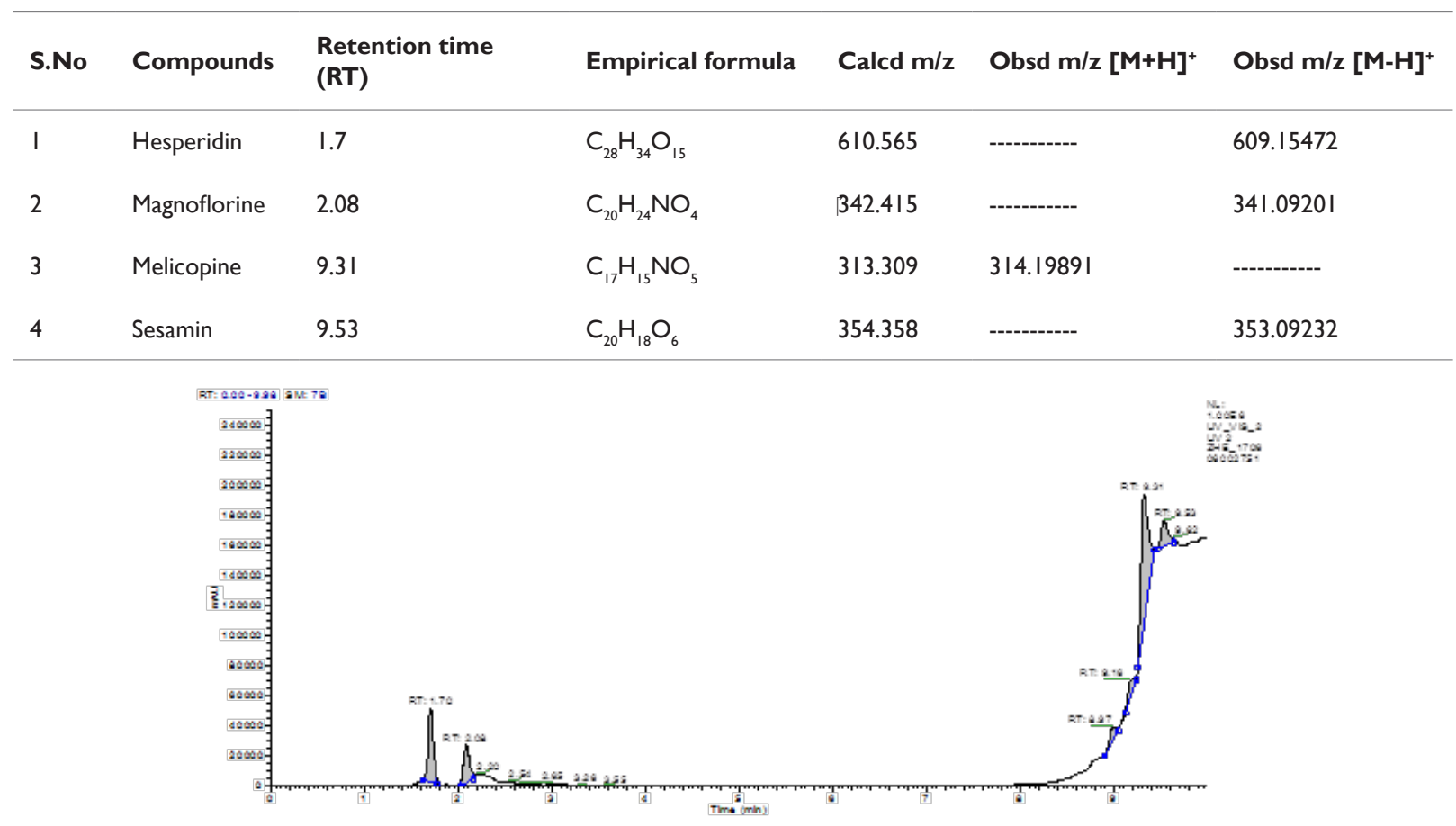

Figure 8 UHPLC chromatogram at $365 \mathrm{~nm}$ of Z. alatum extract.

Citation: Barua CC, Yasmin N, Elancheran R.A review on effective utilization, phytochemical compounds, pharmacological intervention of a popularly used plant for developing a new drug: Zanthoxylum armatum with reference to its anticancer activity. MOJ Bioequiv Availab. 20I8;5(3):I56-I67. 


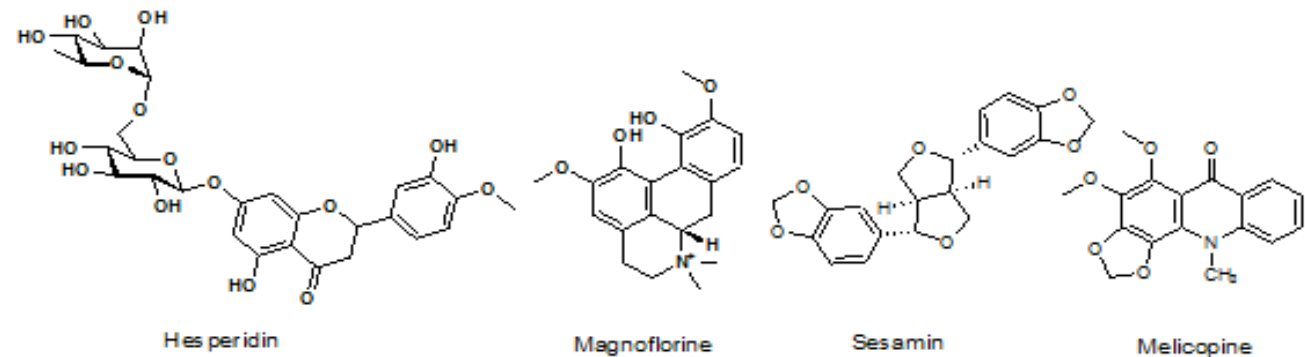

Figure 9 Chemical structures of the identified compounds from the Z. alatum hexane extract.

The $\mathrm{m} / \mathrm{z}$ of the compound:

a. Hesperidin was found to be $610.565[\mathrm{M}-\mathrm{H}]^{+}$(calculated: 610.565$)$ with empirical formula $\mathrm{C}_{28} \mathrm{H}_{34} \mathrm{O}_{15}$.

b. Magnoflorine $\left(\mathrm{C}_{20} \mathrm{H}_{24} \mathrm{NO}_{4}\right)$ was found to be $341.09201[\mathrm{M}-\mathrm{H}]^{+}$ (calculated: 342.415 ).

c. Melicopine was found to be $314.19891[\mathrm{M}+\mathrm{H}]^{+}$(calculated: 313.309) with empirical formula $\mathrm{C}_{17} \mathrm{H}_{15} \mathrm{NO}_{5}$.

d. Sesamin $\left(\mathrm{C}_{20} \mathrm{H}_{18} \mathrm{O}_{6}\right)$ was found to be $353.09232[\mathrm{M}-\mathrm{H}]^{+}$ (calculated: 354.358).

There are also several studies reported that hesperidin has beneficial antioxidant and neuroprotective effects. ${ }^{12-14}$ Magnoflorine has cytotoxic and antiviral activities. ${ }^{15}$ Melicopine is acridone alkaloids with cytotoxic and antimalarial activities. ${ }^{16}$ Sesamin has antinociceptive and anti-Inflammatory activities. ${ }^{17,18}$ By modulating both NMDA receptor and dopaminergic neuronal systems, sesamin ameliorates the effects of chronic EF stress-induced spatial and habit learning memory deficits.

\section{b. Isolation and characterization of lignin ${ }^{19}$}

Lignin isolated from hexane and ethyl acetate fraction and characterize from different analytical techniques. It is a white crystalline compound, which was obtained from hexane:ethyl acetate fraction (10\% polarity) from methanol extract of bark (Figure 10A). It is also a white crystalline compound, which was obtained from hexane:ethylacetate fraction ( $25 \%$ polarity) from methanol extract of bark (Figure 10B).<smiles>O=C(/C=C/c1ccc2c(c1)OCO2)NCCc1ccc2c(c1)OCO2</smiles>

Figure IOA N-(3, 4-Methylene dioxy phenyl ethyl)-3, 4-methylene dioxy cinnamoyl amide.<smiles>COc1ccc(CCNC(=O)CCc2ccc3c(c2)OCO3)cc1OC</smiles>

Figure IOB N-(3, 4-dimethoxy phenyl ethyl)-3, 4-methylene dioxy dihydro cinnamoyl amide.

\section{Chemical Constituents}

The bark of Zanthoxylum armatum contains Alkaloids like g-fagarine, b-fagarine (skimmianine), magnoflorine, nitidine, chelerythrine, tambatarine. Its bark also yields bitter crystalline principle i.e., berberine. The carpels of the tree yields volatile oil, resin, a yellow acid principle and crystalline body, xanthoxyline and sesamin (Figure 11). A volatile oil consisting mainly linalool, $\beta$-sitosterol and its glucoside, tamblin and tambulatin, aramatamide, lignans, asarinin and fragesin, $\alpha$ and $\beta$-amyrinslupeol and $\beta$ - sitosterol $\beta$-D-glycoside have been reported from the plant. ${ }^{19}$<smiles>c1cc2c(cc1[C@@H]1OC[C@H]3[C@H]1CO[C@H]3c1ccc3c(c1)OCO3)OCO2</smiles>

Figure II Sesamin.

Chemical studies on the seeds of Zanthoxylum armatum (Rutaceae) led to the isolation of two new phenolic constituents characterized as 3-methoxy-11-hydroxy-6,8-dimethylcarboxylate biphenyl and 3,5,6,7-tetrahydroxy-3',4'-dimethoxyflavone-5- $\beta$-d-xylopyranoside along with the five known compounds, 1-methoxy-1,6,3anthraquinone, 1-hydroxy-6,13-anthraquinone, 2-hydroxybenzoic acid, 2-hydroxy-4-methoxy benzoic acid and stigmasta-5-en-3 $\beta$ deglucopyranoside, on the basis of spectral data and chemical analyses. ${ }^{20}$

Two new phenolic glycoside, 2-methoxy-4-hydroxylphenyl-1-O$\alpha$-L-rhamnopyranosyl- $\left(1^{\prime \prime} \rightarrow 6^{\prime}\right)-\beta$-D-glucopyranoside and threo-3methoxy-5-hydroxy-phenylpropanetriol-8-O- $\beta$-D-glucopyranoside were isolated from the stems of Zanthoxylum armatum. In DPPH free radical assay with $\mathrm{IC}_{50}$ values of 323 and $114 \mathrm{mM}$ respectively these compounds showed weak scavenging activity. ${ }^{21}$ Monoterpenes like linalool and limonene are the major constituents of the essential oil. Armatamide, an amide was identified from the stem bark of it. Seeds contain hydroxylic (4Z) enolic acid and various volatile compounds. Its stem and roots contains $\beta$-amyrin, $\beta$-sitosterol, lasarinin, L-planinin and zanthobungeanine. The other chemical constituents are methyl cinnamate, limonine, linalool, p-cymene, carvone and palmitic acid etc. $^{22}$ (Figure 12). 
<smiles>COC(=O)/C=C/c1ccccc1</smiles><smiles>C=CC(C)(O)CCC=C(C)C</smiles>

Ethyl cinnamate

Linalool<smiles>C=C(C)C1CC=C(C)CC1</smiles><smiles>Cc1ccc(C(C)C)cc1</smiles>

$$
\text { Limonene }
$$

P-cymene

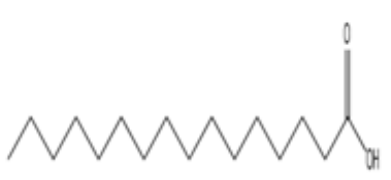

Palmitic acid

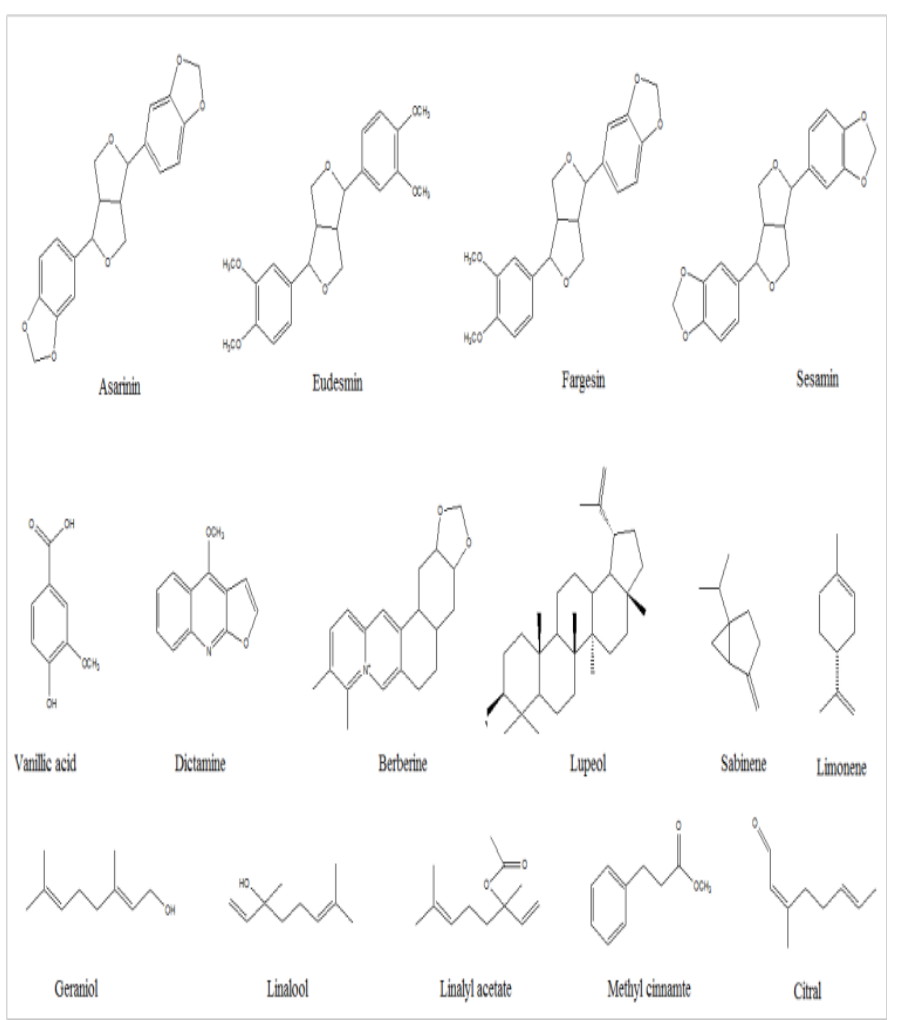

Figure 12 Structures of chemical constituents.

\section{A new amide from Zanthoxylum armatum}

From the bark of Zanthoxylum armatum a new amide designated as armatamide along with two lignans, asarinin and fargesin, alphaand beta-amyrins, lupeol and beta-sitosterol-beta-D-glycoside are isolated. The structure of the new compound was deduced by spectral and chemical analysis as N-(4'-methoxyphenyl ethyl)-3, 4-methylenedioxy cinnamoyl amide. ${ }^{23}$ (Figure 13).<smiles>COc1ccc(CCNC(=O)/C=C/c2ccc3c(c2)OCO3)cc1</smiles>

Armatamide

Figure 13 Structure of Armatamide.

\section{A new lignan from Zanthoxylum armatum}

Guo et al., ${ }^{24}$ isolated a new lignan glycoside, (7S,8R)guaiacylglycerol-ferulic acid, ether-7-O- $\beta$-D-glucopyranoside, along with five known phenylpropanoids and seven phenylpropanoid glycosides (7-13), from the stems of Zanthoxylum armatum DC.

\section{Phytochemical studies}

Vashist et al., ${ }^{25}$ used ethanol and petroleum/ether extract for identification of phytoconstituents with several phytochemical tests and found that some tests give positive results (Table 4).

Table 4 Ethanol and petroleum/ether extract for identification of phytoconstituents with several phytochemical tests

\begin{tabular}{lll}
\hline Plant reagents & $\begin{array}{l}\text { Ethanol } \\
\text { extract }\end{array}$ & $\begin{array}{l}\text { Petroleum I } \\
\text { Ether extract }\end{array}$ \\
\hline Alkaloids & & \\
Mayer's Reagent & + & - \\
Wagner's Reagent & + & - \\
Dragendroff's Reagent & + & - \\
Hager's Reagent & + & - \\
Carbohydrates And & & \\
Glycoside & & - \\
Molish's Reagents & + & - \\
Fehling Solution & + & + \\
Benedict's Reagents & + & - \\
Phytosterol & & - \\
Libermann & + & \\
Burchard's & + & - \\
Terpenes & & - \\
Salkowaski test & + & \\
Antimony trichoride & - & \\
Fixed Oil \& Fats & & - \\
Spot test & & \\
Volatile Oils & & \\
Hydro-distillation & - & \\
\hline
\end{tabular}

\section{Therapeutic uses of Zanthoxylum armatum}

The bark and fruits are useful in asthma, colic, cough, convulsion, cephalalgia, cardiac debility, diabetes, diarrhoea, dyspepsia, fever, flatulence, general debility, goitre, difficult micturition, eye and ear diseases, helminthiasis, hepatopathy, leprosy, leucoderma, odentalgia, otopathy, paralysis, pharyngopathy, skin disease, splenopathystrangury, stomach disorders, tumors, ulcers and wounds. ${ }^{26}$ The seeds are useful in cholera, expulsion of intestinal worms to strengthen the liver to remove foul smell from mouth and in brain disease and insanity. The 
branches are used as a brush to keep teeth hygienic and to strengthen the gum. The flowers are used as antidote for snake bite. ${ }^{27}$ The seed powder is smoked in asthma and bronchitis. ${ }^{28}$ (Table 5).

Table 5 Medicinal properties of different parts of Z. Armatum. ${ }^{29}$

\begin{tabular}{llll}
\hline $\begin{array}{l}\text { Sr. } \\
\text { No. }\end{array}$ & Activity & Active part & Preparation \\
\hline I & $\begin{array}{l}\text { Antioxidative } \\
\text { activity }\end{array}$ & Fruits & Methanolic extract,
\end{tabular}

Ethanolic extract

$\begin{array}{llll}2 & \text { Antitumor activity } & \text { Leaves/Fruits } & \text { Ethanolic extract } \\ 3 & \begin{array}{l}\text { Anti-inflammatory } \\ \text { activity }\end{array} & \text { Stem Bark } & \text { Ethanolic extract, } \\ & & \text { Fruit, Root } & \begin{array}{l}\text { Methanolic extract, } \\ \text { Ether extract }\end{array} \\ 4 & \text { Analgesic activity } & \text { Leaves/Stem } & \text { Ethanolic extract } \\ 5 & \begin{array}{l}\text { Antibacterial } \\ \text { activity }\end{array} & \text { Seeds/Leaves } & \text { Essential oils } \\ 6 & \text { Antifungal activity } & \text { Leaves } & \text { Essential oils } \\ 7 & \text { Larvicidal activity } & \text { Fruits/seeds } & \text { Essential oils } \\ 8 & \text { Pesticidal activity } & \text { Fruit } & \text { Essential oils } \\ 9 & \begin{array}{l}\text { Hepatoprotective } \\ \text { activity }\end{array} & \text { Leaves/Bark } & \text { Essential oils }\end{array}$

\section{Pharmacological studies on Zanthoxylum armatum}

\section{Hepatoprotective activities}

Ethanolic extract of Zanthoxylum armatum exhibited hepatoprotective effect against carbon tetrachloride-induced liver damage by normalizing the elevated levels of the hepatic enzymes. Ethanolic extract of Zanthoxylum armatum is able to condition the hepatocytes, protecting against membrane fragility and decreases the leakage of the marker enzymes into the circulation as compared to silymarin, reported to have protective effect on the plasma membrane of hepatocytes. ${ }^{29}$

\section{Anti-diabetic activity}

Hydro methanolic extract of the bark of Zanthoxylum armatum was evaluated for its anti diabetic activity in streptozotocin $(60 \mathrm{mg} /$ $\mathrm{kg})$ induced diabetic in rats. Glibenclamide $(5 \mathrm{mg} / \mathrm{kg})$ was used as the standard reference drug. Oral administration of Hydro methanolic extract of Zanthoxylum armatum for 21 days $(200$ and $400 \mathrm{mg} / \mathrm{kg}$ ) resulted in significant reduction in blood glucose, total cholesterol, triglycerides, LDL, VLDL and significant increase of HDLP. ${ }^{30}$

\section{Antidepressant activity}

In our laboratory, we have studied various extracts of $Z$. alatum for its antidepressant property. Bioassay guided fraction was done in order to find out the most active component as antidepressant. Its hexane extract showed maximum potency, followed by hydroalcoholic extract in various models of depression like Forced swimming model in rat and mice and tail suspension test in mice. The behavioural as well as biochemical and molecular studies have shown that the seed of the plant possesses significant antidepressant property. ${ }^{31}$

\section{Memory enhancing property}

So far Z. alatum was not studied for its effect on neurological disorders. It is used by locals for tooth ache, as stimulant or nerve tonic in weak, debilitated patient as a folk lore medicine. We, for the first time conducted detail study as memory enhancer using various extracts and its hydroalcoholic extract reverted scopolamine induced amnesia in mice, which was subsequently substantiated with biochemical, immunological, molecular study as well. ${ }^{32}$

\section{Cytotoxicity}

Mukhija et al., ${ }^{33}$ used ethyl acetate extract of stem bark of Zanthoxylum alatum for its cytotoxic and antioxidant potential. Cytotoxicity of ethyl acetate extract was studied on different cancerous cell lines such as pancreatic, lung, breast and colon cancer using MTT assay. The extract of plant has shown significant cytotoxic potential on lung and pancreatic cancer cell lines. Flavonoids isolated from ethyl acetate extract were responsible for cytotoxic activity of the extract.

Sixteen medicinal plants extracts were screened from North east part of India and found that the leaf extract of Zanthoxyllum armatum (ZALE) induced cytotoxicity. Zanthoxyllum armatum leaf extract have the potential effect on increasing the efficiency of chemotherapeutic drugs like camptothecin, mitomycin C and cisplatin. ${ }^{34}$ In this study, HeLa cells with $80 \mu \mathrm{g} / \mathrm{ml}$ was treated with ZALE for almost 48 hours. It shows morphological changes and cytotoxicity in dose dependent manner. Apoptosis was characterized by membrane blebbing. To know the molecular mechanism of apoptosis induced ZALE, caspase - 3 activation and PARP (Poly ADP-ribose polymerase) cleavage is analyzed by immunoblotting. Caspases are catalytically inactive zymogen activated by the proteolytic cleavage. The ZALE treated cells does not show caspase 3 activation nor PARP cleavage which suggest apoptosis without activating caspase 3 and PARP cleavage. Recent reports also show ZALE activates the MAPK (mitogenactivated protein kinases) pathway. Further to investigate, whether the plant extracts enhance apoptosis induced by chemotherapeutic drugs, HeLa cells with low dose approximately $15 \mu \mathrm{g} / \mathrm{ml}$ of the plant extract were kept for 16 hours and then exposed to the drug cisplatin for 48 hours. The cell proliferation assay shows greater cell death in combination treatment in comparison to only extract treatment. ZALE shows 70 percent more killing cells which suggests ZALE also augmented chemotherapeutic drugs induced apoptosis (Figure 14).

Karmakar et al., ${ }^{35}$ used different extract (methanol, chloroform, petroleum ether) of Zanthoxylum alatum for its antioxidant and cytotoxic activity. The antioxidant activities of all the three above mentioned extracts of Zanthoxylum alatum were measured by different in vitro standard methods like 1,1-diphenyl-2-picrylhydrazil radical (DPPH), superoxide anions, nitric oxide, hydroxyl radicals and reductive assay. On the basis of antioxidant properties total phenolic, total flavonoid, $\mathrm{CCl}_{4}$-induced in vivo antioxidant and in vitro cytotoxicity were measured for methanol extract of Zanthoxylum alatum (MEZA). In vitro cytotoxic effect was conducted for methanol extract of Zanthoxylum armatum (MEZA) in Ehrlich Ascites Cancer (EAC) cells in Swiss albino mice by trypan blue exclusion method. It showed direct cytotoxic effect of MEZA on the EAC cell line. MEZA showed satisfactory phenolic and flavonoid content which support the cytotoxicity with IC50 value $102.30 \pm 0.81 \mu \mathrm{g} / \mathrm{mL}$, thus indicating preliminary positive results in cytotoxic activity. The study showed that among all the three extract MEZA has better dose dependant antioxidant and cytotoxic activity. 


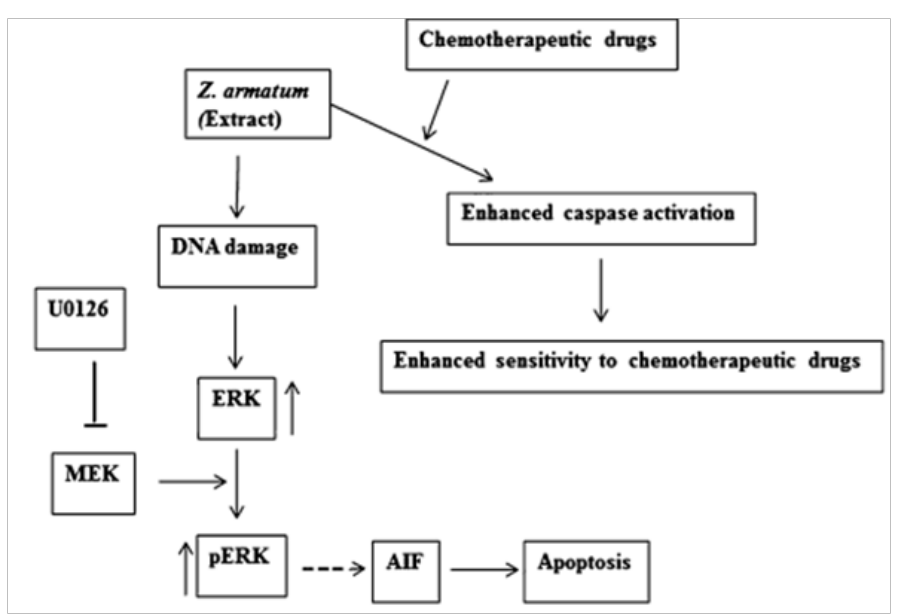

Figure I4Theoritical mechanism of ZALE mediated cell death. ZALE induced DNA damage and ERK (extracellular signal-regulated kinases) activation. AIF (Apoptosis-inducing factor) is released by activation of ERK which lead to apoptosis in caspase independent manner. Also treatment of ZALE with chemotherapeutic drugs enhanced caspase activation leading caspase dependent apoptosis.

Alam et al., ${ }^{36}$ used methanol extract and the crude saponins from fruit, bark and leaves of $Z$. armatum for its anticancer effects on breast (MDA-MB-468 and MCF-7) and colorectal $\left(\mathrm{Caco}^{-2}\right)$ cancer cell lines using MTT, neutral red uptake (NRU) and DAPI stain assays. The effect of saponins from fruit, bark and leaves (Zf. Sa, Zb.Sa and $Z l$. $\mathrm{Sa}$ ) against $\mathrm{Caco}^{-2}$ cell lines inhibited the growth of $\mathrm{Caco}^{-2}$ by 53.16 $( \pm 3.31) \%, 66.43( \pm 3.24)$ and $45.96( \pm 10.67)$ respectively with respect to Actinomycin-D $(4 \mu \mathrm{M})$ which showed the growth inhibition of $65.40( \pm 4.29) \%$. In clinical uses recently saponins are widely used as chemotherapeutic agents. Saponins can inhibit the growth of tumor cells by apoptosis through signaling pathways without altering the normal colon morphology when examined against colon cancer cell lines.

Barkatullah et al., ${ }^{37}$ did in-vitro and in-vivo pharmacological screening of Zanthoxylum armatum and used crude ethanolic and n-hexane extract of the leaves (ZLE, ZLH) and fruits (ZLE, ZLH) of this plant for evaluation of phytotoxic and cytotoxic potential. Phytotoxicity and cytotoxicity were found to be dose dependant and showed maximum efficiency at $1000 \mu \mathrm{g} / \mathrm{ml}$. This study demonstrates that crude saponins and extract from leaves, bark and fruit of Zanthoxylum armatum exert cytotoxic effect on cancer cell lines involving apoptosis.

Another study done by Barkatullah et al., ${ }^{38}$ showed Brine Shrimp Toxicity bioassay is preliminary study for the detection and development of anti-cancer drugs. Brine shrimp lethality tests were carried out to investigate preliminary cytotoxic potential of the crude ethanolic and n-hexane extract of leaf, bark, fruit and leaf essential oil of $Z$. armatum. Essential oil from Zanthoxylum armatum showed outstanding mortality rate $(100 \%)$ at a dose of $1000 \mu \mathrm{g} / \mathrm{ml}$ with 15.90 $\mathrm{LC}_{50}$ values. It is needed to carry further detailed investigations for identification and quantification of pharmacologically bioactive specific constituents from $Z$. armatum.

\section{Cardiovascular disorders}

The crude extract of Zanthoxylum armatum exhibits anti arrhythmic, spasmolytic effects which are mediated probably through
$\mathrm{Ca}^{++}$antagonist mechanism which may be the pharmacological basis for its medicinal use in GIT, respiratory and cardiovascular disorders. This mechanism is explained by pretreatment of calcium channel blocker Verapamil. ${ }^{39}$

\section{Anti-inflammatory and antioxidant activities}

Ethanolic extract of steam bark of Zanthoxylum armatum was studied for anti-inflammatory and antioxidant activities. In vivo antiinflammatory activity in Wister rats by using Carrageenan induced paw edema, in vitro antioxidant activity was performed by DPPH free radical method. The plant extract exhibited significant antiinflammatory and antioxidant activities. ${ }^{40}$

\section{Anti-microbial activity}

Antimicrobial efficacy of Zanthoxylum armatum was evaluated against four different bacterial strains i.e. S. aureus, E. coli, P. vulgaris and $P$. aeruginosa. The antibacterial activity was studied using chloroform, methanol and acetone extracts of Zanthoxylum alatum bark using well diffusion method. Highest zone of inhibition was observed in acetone extract against $\mathrm{S}$. aureus $(42.3 \mathrm{~mm})$ followed by methanolic extract against $S$. aureus $(28.7 \mathrm{~mm})$, while the highest activity was found in chloroform extract against P.vulgaris $(28.3 \mathrm{~mm})$. The methanol and acetone extract of bark showed more potency for $S$. aureus and chloroform extract for P. Vulgaris. ${ }^{41}$

\section{Larvicidal activities}

Larvicidal potential of the essential oil from the seeds of Zanthoxylum armatum against three medically important species of mosquito vectors, Aedesa egypti, Anopheles stephensi and Culex quinquefasciatus. Study of essential oil yielded at least 28 compounds, consisting mainly of oxygenated monoterpenes. The larvae of these mosquito species were susceptible to the essential oil composition and shows potential for the development of alternative plant based larvicides. In this context, essential oils have received much attention as potentially useful bioactive compounds against insects showing a broad spectrum of activity against insects, low mammalian toxicity and degrading rapidly in the environment. ${ }^{42}$

\section{Mosquito and insect repellent}

Essential oil of Z. armatum possesses leech or insect repellent activity. Experiments on persistent of repellent properties of $\mathrm{N}$, $\mathrm{N}$-diethyl phenyl acetamide (DEPA), N, N-diethyl-m-toluamide (DEET), 3-acetyl-2 (2,6-dimethyl-5-heptenyl) oxazolidine (citronyl), dimethyl phthalate (DMP) and N-benzoyl piperidine (NBP) on cloth were tested against land leeches in evergreen rain and deciduous forests of Assam. Results obtained were compared with its volatile oil to evaluate its efficacy as a leech repellent. Z. armatum oil was at par with citronyl and exhibited better results than DMP and NBP though DEPA and DEET were found to be the best. ${ }^{43}$

\section{Anthelmintic activity}

The anthelmintic activity of the seeds extracted with methanol and water by maceration process. Due to its physiological and anatomical resemblance with the intestinal round worm of human being the assay was performed on adult Indian earthworms Pheretima posthuma. The extract was tested with different concentrations 10,25 and $50 \mathrm{mg} / \mathrm{ml}$. Piperazine citrate $(10 \mathrm{mg} / \mathrm{ml})$ was used as the standard reference drug. Results showed that the aqueous extract is more potent as compared to other extract as it took less time to cause paralysis and death of the earthworms as compared to standard reference drug. The Aqueous 
extract of the leaves showed antiprotozoal effect on Giardia Lamblia, Plasmodium berghei. ${ }^{44}$

\section{Anti-spasmodic activity}

Results showed Zanthoxylum armatum exhibits spasmolytic effects, mediated possibly through $\mathrm{Ca}^{++}$antagonistic mechanism, which provides pharmacologic base for its medicinal use in the gastrointestinal, respiratory and cardiovascular disorders. All the samples were tested against spontaneous and potassium chloride induced contracted smooth muscle of the isolated rabbit jejunum. To determine the possible mode of action, the tissue was pre-treated with high concentration of $\mathrm{KCl}(80 \mathrm{~mm}$ in final bath solution). $\mathrm{KCl}$ causes depolarization and keeps the tissue in a position of sustained contraction. The test samples were then applied in cumulative manner to obtain a dose dependent curve and relaxation results were expressed as percentage of $\mathrm{KCl}$ induced contraction. The spasmolytic effect of the oils started from $0.03 \mathrm{mg} / \mathrm{ml}$ and showed $100 \%$ effect at $10 \mathrm{mg} /$ $\mathrm{ml}$ dose. ${ }^{45}$

Zanthoxylum armatum hexane extract (ZAHE) has spasmolytic effects on isolated preparation of rat ileum, fundus, and guinea pig ileum. It could antagonize Acetylcholine, 5-hydroxytryptamine, and histamine-induced contraction in the isolated tissues of rat and guinea pig. The effects were similar to muscarinic blocker atropine, ketanserin, the 5-HT antagonist, and/or pheniramine maleate, the antihistaminic drug. ${ }^{46}$ ZAHE inhibited histamine-induced contraction of guinea pig ileum in concentration-dependent manner. Histamine produced a concentration-dependent membrane depolarization and increased excitability on smooth muscle. ${ }^{47,48}$ Contractile effects of histamine on the isolated guinea pig ileum are known to be mediated through $\mathrm{H} 1$ histamine receptors. ${ }^{49}$ ZAHE inhibited histamineinduced contraction of guinea pig ileum comparable to the standard antihistaminic pheniramine maleate. Antagonist activity of ZAHE against histamine-induced contraction supports the traditional use of $\mathrm{ZA}$ in cough and chest infection, etc. ${ }^{50} \mathrm{EC}_{50}$ values of Zanthoxylum armatum extract also shows anticholinergic, anti serotonergic and antihistaminic activity.

\section{Antinociceptive and anti convulsant activity}

Hydro steam distillation of essential oils of the leaves of Zanthoxylum alatum (ZEO) was evaluated for acute toxicity, antinociceptive and anticonvulsant activities. ZEO significantly relieves the pain in both neurogenic (first phase) and inflammatory (late phase) phases in formalin induced noxious animal and found ant convulsive effect in pentylene tetrazole (PTZ) induced convulsion. ${ }^{51}$

\section{Antiproliferative activity}

Methanol extract obtained from Zanthoxylum armatum bark was screened for their antiproliferative activity against growth of human keratinocytes (HaCaT cells) along with four other different Zanthoxylum species. It was found Zanthoxylum armatum bark was bark was highly active with $\mathrm{IC}_{50}$ value of $11 \mu \mathrm{g} / \mathrm{ml}$. Extracts obtained from Zanthoxylum oxyphyllum roots and bark showed effective activity with $\mathrm{IC}_{50}$ values of 57 and $53 \mu \mathrm{g} / \mathrm{ml}$ respectively. Antiproliferative activity was not due to the cytotoxic effects on cell membranes rather they protect against the radical-induced-damage to model membranes stimulated with 2,2'-azo-bis(2-amidinopropane) dihydrochloride..$^{52}$

\section{Soothing effect on skin}

The lipophilic extract with alcohol gives remarkable soothing effect based on inhibition of sensory irritation from sun bathing, shaving depilation, insect bites and chemical treatment. ${ }^{53}$

\section{Toxic effects of Z. armatum}

The toxicities of the preparations - extracts, decoctions and paste are studied by many researchers. The aqueous extracts of dried fruit of Zanthoxylum armatum which are used extensively in traditional herbal remedies exert their toxic potential in vivo by inducing membrane damage of cellular organelles, chromatin condensation, chromatin marginalization, chromosome clumping and nuclear DNA damage resulting in subsequent mitotic arrest. ${ }^{54}$

\section{Ayurvedic pharmacopoeia of Zanthoxylum armatum ${ }^{55}$}

Tumburu consists of dried fruit of Zanthoxyllum armatum DC.

Syn. Z. alatum Roxb, Essential oil is the main derivative of Tumburu.

\section{Properties and action}

Rasa: Katu

Guna: Tikta

Virya: Laghu, RukÀa, ÙikÀ ,a

Vipaka: Katu

Karma: Dipana, Kaphahara, Pacana, Rucya, Vatahara, Lalapraseka, Cimcimayanama, Rasana Samsvedaka.

Therapeutic uses: Arsa, Agnimandya, Hrdroga, Hikka, Kasa, Kantha Roga, Svasa, Ardita, Kaphaja Roga, Asya Roga, Danta Roga.

Important Formulations: Hingvadi Taila, Saptavimsati Guggulu, Maha Visagarbha Taila, Dadhika Ghrta.

\section{Uses described in folk medicine}

The collection of Zanthoxylum armatum plant for food, medicine and barter is a culture of Bhotiya transhumant pastoral communities in the Uttaranchal Himalaya of India. ${ }^{56}$ Different social groups and geographical regions have adopted different strategies for their acquisition of timur. The ethnic group Bhotiya tribal community uses the fruit in the form of condiments, spices and medicine. The fruit is used in curing various common ailments such as toothache, common cold, cough and fever. To cure toothache, the fresh or dry fruit is pressed over the affected tooth in a position tili it loses its pungency. The fruit soup is used for stomach problems.

The Bhotiya community brew liquor from the fruit. The bark, fruits and seeds of $Z$. armatum are extensively used in indigenous system of medicine as a carminative also the fruits and seeds of $Z$. armatum are used as aromatic tonic in fever and dyspepsia. The bark is used for the treatment of cholera. ${ }^{57}$ In China an infusion in vinegar is used to expel bugs or worms infecting ear. ${ }^{58}$ The plant is used for the treatment of scabies used as a lotion applied in the skin..$^{59} \mathrm{Z}$. armatum also shows stimulating effect upon the lymphatic system, circulation and act as stimulation liniment for rheumatism and fibrositis. ${ }^{60}$

Since ancient times, the plant Zanthoxylum armatum is traditionally used and have been of much interest due to its historical claims as well as anticancer properties. Several other species of this genus have previously shown to have cytotoxicity against various human cancer and tumor cell lines. Hence the cytotoxic activity of the extracts of Zanthoxylum armatum corresponds well with the cytotoxic potential of this genus. ${ }^{61}$ 


\section{Conclusion}

Medicinal plants have contributed hugely to the traditional and western medicines providing ingredients for drugs or having played central roles in the drug discovery. Zanthoxylum armatum is extensively used in the Indian system of medicine. The above study provides the updated information regarding Zanthoxylum armatum. It is not a fast-growing species and has low population sizes. The proliferation of woody weeds such as Lantana in Zanthoxylum armatum growing areas is creating problems for the survival of this native species. Some of the mechanisms of collection adopted by the local people are harmful to existing populations. However, the main question is whether Zanthoxylum armatum shrubs can be conserved when the race for commercial tapping of its fruit is escalating, and when maximizing income is the chief concern of local harvesters. Recognizing the current demand, Zanthoxylum armatum plantations can be developed as a viable source of income for resource-poor villagers. Zanthoxylum armatum can be grown on marginal and unproductive land and also in forested land as an understory shrub. A proper agronomic study is required to assess the viability of economic gain by farming Zanthoxylum armatum.

\section{Acknowledgements}

The authors express their sincere thanks to the Director of Research (Vety), AAU, Khanapara for providing facility to carry out this work.

\section{Financial support and sponsorship}

DBT, New Delhi, India

\section{Conflicts of interest}

The author declares that there are no conflicts of interests involved in this study.

\section{References}

1. Singh TP, Singh OM. Phytochemical and Pharmacological profile of Zanthoxylum armatum DC. An overview. Indian J Nat Prod Res. 2011;2(3):275-285.

2. Ramidi R, Ali M, Negueruela AV, et al. Chemical composition of the seed oil of Zanthoxylum alatum Roxb. J Essent Oil Res. 1998;10(2):127-130.

3. Annappan U, Rajkishore VB, Ramalingam RA. Review on Zanthoxylum alatum Roxb. Res J Pharmacog Phytochem. 2015;7(4):223-226.

4. Batool F, Sabir SM, Rocha JBT, et al. Evaluation of antioxidant and free radical scavenging activities of fruit extract from Zanthoxylum alatum: a commonly used spice from Pakistan. Pak J Bot. 2010;42(6):4299-4311.

5. Vana PD. Agro-technique study carried out by Regional Station, National Bureau of Plant genetic Resources, Dist Niglat, Nainital, Uttarakhand and B-RRL, CSIR, Itanagar, Arunachal Pradesh, Teri Press. India, New Delhi; 2008:231-234.

6. Barkatullah IM, Ikram N, Rauf A, et al. Toxicological profile of ethanolic extract of leaves and barks of Buddleja asiatica Lour. Middle-East J Sci Res. 2014;21(9):1655-1658.

7. Chatterjee A, Pakrashi SC. The Treatise of Indian Medicinal Plants. India, Publication and Information Directorate New Delhi; 1994:115-116.

8. Alam F, Us Saqib QN. Pharmacognostic study and development of quality control parameters for fruit, bark and leaves of Zanthoxylum armatum (Rutaceae). Ancient Sci Life. 2015;34(3):147-155.

9. Quality Control Method for Medicinal Plant Materials. Switzerland, Geneva, WHO; 2002:122 p.
10. Monteiro ÉM, Chibli LA, Yamamoto $\mathrm{CH}$, et al. Antinociceptive and anti-inflammatory activities of the sesame oil and sesamin. Nutrients. 2014;6(5):1931-1944

11. Kayat HP, Gautam S, Jha RN. GC-MS analysis of hexane extract of Zanthoxylum armatum DC Fruits. Indian $J$ Pharmacog Phytochem. 2016;5(2):58-62.

12. Kumari S, Elancheran R, Kotoky J, et al. Rapid screening and identification of phenolic antioxidants in Hydrocotyle sibthorpioides Lam. by UPLC-ESI-MS/MS. Food Chem. 2016;203:521-529.

13. Bhatt V, Sharma S, Kumar N, et al. Simultaneous quantification and identification of flavonoids, lignans, coumarin and amides in leaves of Zanthoxylum armatum using UPLC-DAD-ESI-QTOF-MS/MS. J Pharm Biomed Anal. 2017;132:46-55.

14. Kumar V, Kumar S, Singh B, et al. Quantitative and structural analysis of amides and lignans in Zanthoxylum armatum by UPLC-DAD-ESIQTOF-MS/MS. J Pharm Biomed Anal. 2014;94:23-29.

15. Cho J. Antioxidant and neuroprotective effects of hesperidin and its aglycone hesperetin. Arch Pharm Res. 2006;29(8):699-706.

16. Mohamed SM, Hassan EM, Ibrahim NA. Cytotoxic and antiviral activities of aporphine alkaloids of Magnolia grandiflora L. Nat Prod Res. 2010;24(15):1395-1402.

17. Wang C, Wan J, Mei Z, et al. Acridone alkaloids with cytotoxic and antimalarial activities from Zanthoxylum simullans Hance. Pharmacogn Mag. 2014;10(37):73-76.

18. Zhao TT, Shin KS, Park HJ, et al. Effects of (-)-sesamin on chronic stressinduced memory deficits in mice. Neurosci Lett. 2016;634:114-118.

19. Siddhanadham AS, Yejella RP, Prava R, et al. Isolation, characterization and biological evaluation of two new lignans from methanolic extract of bark of Zanthoxylum armatum. Int $J$ Pharmacog Phytochem. 2017;9(3):395-399.

20. Akhtar N, Ali M, Alam MS. Chemical constituents from the seeds of Zanthoxylum alatum. J Asian Nat Prod Res. 2008;11(1):91-95.

21. Guo T, Dai LP, Tang XF, et al. Two new phenolic glycosides from the stem of Zanthoxylum armatum DC. Nat Prod Res. 2017;31(20):2335-2340.

22. Krishnamurthi A. The Wealth of India: Raw Materials-Vol. VIII. India, New Delhi, Publications and Information Directorate, Council of Scientific and Industrial Research; 1969:394 p.

23. Kalia NK, Singh B, Sood RP. A new amide from Zanthoxylum armatum. J Nat Prod. 1999;62(2):311-312.

24. Guo T, Tang XF, Chang J, et al. A new lignin glycoside from the stems of Zanthoxyllum armatum DC. Nat Prod Res. 2017;31(1):16-21.

25. Vashist H, Sharma RB, Sharma D, Upmanyu N. Pharmacological activities on Zanthoxylum armatum- A review. World J Pharm Pharm Sci. 2016;5:408-423.

26. Kala CP, Farooquee NA, Dhar U. Traditional uses and conservation of Timur (Zanthoxylum armatum DC) through social institutions in Uttaranchal Himalaya, India. Conserv Soc. 2005;3(1):224-230.

27. Deshpande DJ. A Hand Book of Herbal Remedies. India, Agrobio; 2005:408-409.

28. Anonymous. The Wealth of India-A Dictionary of Indian Raw Materials \& Industrial Products: Raw Materials. Vol. XI (X-Z). India, New Delhi, Publication and Information Directorate, CSIR; 2005:568 p.

29. Verma N, Khosa RL. Hepatoprotective activity of leaves of $Z$ armatum $\mathrm{DC}$ in CCl4-induced hepatotoxicity in rats. Indian J Biochem Biophys. 2010;47(2):124-127.

30. Karki H, Upadhayay $\mathrm{K}$, Pal $\mathrm{H}$, et al. Antidiabetic potential of

Citation: Barua CC, Yasmin N, Elancheran R.A review on effective utilization, phytochemical compounds, pharmacological intervention of a popularly used plant for developing a new drug: Zanthoxylum armatum with reference to its anticancer activity. MOJ Bioequiv Availab. 20I8;5(3):I56-I67. 
Zanthoxylum armatum bark extract on streptozotocin-induced diabetic rats. Int J Green Pharm. 2014;8(2):77-83.

31. Barua CC, Haloi P, Saikia B, et al. Zanthoxyllum alatum abrogates lipopolysaccharides-induced depression-like behaviours in mice by modulating neuroinflammation and monoamine neurotransmitters in the hippocampus. Pharm Biol. 2018;56(1):245-252.

32. Saikia B, Barua CC, Sarma J, et al. Zanthoxyllum alatum ameliorates scopolamine-induced amnesia in rats: Behavioral, biochemical and molecular evidence. Indian J Pharmacol. 2018;50(1):30-38.

33. Mukhija M, Singh MP, Dhar KL, et al. Cytotoxic and antioxidant activity of Zanthoxylum alatum stem bark and its flavonoid constituents. $J$ Pharmacog Phytochem. 2015;4(4):86-92.

34. Singh TD, Meitei HT, Sharma AL, et al. Anticancer properties and enhancement of therapeutic potential of cisplatin by leaf extract of Zanthoxylum armatum DC. Biol Res. 2015;48:46.

35. Karmakar I, Haldar S, Chakraborty M, et al. Antioxidant and cytotoxic activity of different extracts of Zanthoxylum alatum. Free Rad Antioxidants. 2015;5(1):21-28.

36. Alam F, Najum Us Saqib Q, Waheed A. Cytotoxic activity of extracts and crude saponins from Zanthoxylum armatum DC. Against human breast (MCF-7, MDA-MB-468) and colorectal (Caco-2) cancer cell lines. BMC Complement Altern Med. 2017;17(1):368.

37. Barkatullah B, Ibrar M, Muhammad N. Evaluation of Zanthoxylum armatum DC for in-vitro and in-vivo pharmacological screening. African J Pharm Pharmacol. 2011;5(14):1718-1723.

38. Barkatullah B, Ibrar M ,Muhammad N, et al. Chemical Composition and Biological Screening of Essential Oils of Zanthoxylum armatum DC Leaves. J Clin Toxicol. 2013;3:1-6.

39. Gilani SN, Khan A, Gilani AH. Pharmacological basis for the medicinal use of Z. armatum in gut, airways, and cardiovascular disorders. Phytother Res. 2010;24(4):553-558.

40. Sati SC, Sati MD, Rakesh R, et al. Anti-Inflammatory and antioxidan activities of Zanthoxylum armatum stem bark. J Gen Engineering. 2011;11(5):19-21.

41. Srivastava N, Kainthola A, Bhatt AB. In-vitro antimicrobial activity of bark extract of an ethnic plant Zanthoxylum alatum DC against selected human pathogens in Uttarakhand Himalaya. Int $J$ Herb Med. 2013;1(3):21-24.

42. Tiwary M, Naik SN, Tewari D, et al. Chemical composition and larvicida activities of the essential oil of Zanthoxylum armatum DC (Rutaceae) against three mosquito vectors. J Vect Borne Dis. 2007;44:198-204.

43. Dube S, Kumar A, Tripathi SC. Antifungal and insect repellent activity of essential oil of Zanthoxylum armatum linn. Curr Sci. 1961;30:223-224.

44. Mehta DK, Das R, Bhandari A. In-vitro anthelmintic activity of seed of Zanthoxylum alatum DC. against Pheretima posthuma. Int J Green pharmacy. 2012;6(1):26-28.

45. Barkatullah B, Ibrar M, Ali N, et al. Antispasmodic potential of leaves, barks and fruits of Zanthoxylum armatum DC. African J Pharm Pharmacol. 2013;7(13):685-693.
46. Saikia B, Barua CC, Haloi P, et al. Anticholinergic, antihistaminic, and antiserotonergic activity of $\mathrm{n}$-hexane extract of Zanthoxylum alatum seeds on isolated tissue preparations: An ex vivo study. Indian $J$ Pharmacol. 2017;49(1):42-48.

47. Hemming JM, Guarraci FA, Firth TA, et al. Actions of histamine on muscle and ganglia of the guinea pig gallbladder. Am J Physiol Gastrointest Liver Physiol. 2010;279(3):622-630.

48. Matsumoto T, Horiuchi M, Kamata K, et al. Effects of Bidens pilosa L. var. radiata SCHERFF treated with enzyme on histamine-induced contraction of guinea pig ileum and on histamine release from mast cells. J Smooth Muscle Res. 2009;45(2-3):75-86.

49. Black JW, Duncan WA, Durant CJ, et al. Definition and antagonism of histamine $\mathrm{H}_{2}$-receptors. Nature. 1972;236:385-390.

50. Geweli MB, Awale S. Aspects of Traditional Medicine in Nepal. Japan: Institute of Natural Medicine University of Toyama; 2008:140-142.

51. Muhammad I, Naveed M, Barkatullah HK, et al. Antinociceptive and anticonvulsant activities of essential oils of Zanthoxylum alatum. Phytopharmacol. 2012;3:191-198.

52. Kumar S, Muller K. Inhibition of keratinocyte growth by different Nepalese Zanthoxyllum species. Phytother Res. 1999;13(3):214-217.

53. Guglielmini G, Cristoni A. Zanthoxylum armatum extract inhibits skin sensitivity. Cosmet Toilet. 2002;117(7):47-54.

54. Kharshiing EV. Aqueous extracts of dried fruits of Zanthoxylum armatum DC (rutaceae) induce cellular and nuclear damage coupled with inhibition of mitotic activity in vivo. Am J plant Sci. 2012;3(11):1646-1653.

55. The Ayurvedic Pharmacopoeia of India, Part 1, Vol-IV, Government of India, Department of Ayush. India: 183 p.

56. Farooquee NA. Transhumance in the Central Himalaya: A Study of its Impact on Environment. Srinagar, Garhwal: Garhwal University; 1994.

57. Singh TP, Singh OM. Phytochemical and Pharmacological profile of Zanthoxylum armatum DC. An overview. Indian J Nat Prod Res. 2011;2(3):275-285.

58. Watson E. The Principal Articles of Chinese Commerce. 2nd ed. Shanghai: Statistical Department of the Inspectorate General of Customs; 2013:491.

59. Roi Jacques SJ. Traite des plantes medicinales chinoises. Paris: Lechevalier; 1955:198 p.

60. Brijwal L, Pandey Aseesh, Tamta S. An overview on phytomedicinal approaches of Zanthoxylum armatum DC: An important magical medicinal plant. J Med Plant Res. 2013;7(8):366-370

61. Özkan M, Mutiso PB, Nahar L, et al. Zanthoxylum usambarense (Engl.) Kokwaro (Rutaceae) extracts inhibit the growth of the breast cancer cell lines MDA-MB-231 and MCF-7, but not the brain tumour cell line U251 in vitro. Phytother Res. 27(5):787-790. 